\title{
Selective $\mathrm{CB}_{2}$ up-regulation in women affected by endometrial inflammation
}

\author{
Teresa luvone ${ }^{a, *}$, Daniele De Filippis ${ }^{a}$, Attilio Di Spiezio Sardo ${ }^{b}$, \\ Alessandra D'Amico ${ }^{a}$, Sara Simonetti ${ }^{c}$, Stefania Sparice ${ }^{b}$, Giuseppe Esposito ${ }^{a}$, \\ Giuseppe Bifulco ${ }^{\text {b }}$, Luigi Insabato ${ }^{\text {c }}$, Carmine Nappi ${ }^{\text {b, Maurizio Guida }}{ }^{\text {b }}$ \\ ${ }^{a}$ Endocannabinoid Research Group, Department of Experimental Pharmacology, Faculty of Pharmacy, \\ University of Naples, 'Federico II', Naples, Italy \\ ${ }^{b}$ Department of Gynecology and Obstetrics and Pathophysiology of Human Reproduction, \\ University of Naples, 'Federico II', Naples, Italy \\ ${ }^{c}$ Department of Biomorphologic and Functional Sciences, Pathology Section, \\ University of Naples 'Federico II', Naples, Italy
}

Received: April 19, 2007; Accepted: June 7, 2007

\section{Abstract}

Endometritis is defined as an inflammation of the endometrial mucosa of the uterus. In endometritis large amounts of toxic mediators, including nitric oxide (NO) are released by inflammatory cells. As a consequence of nitric oxide-dependent injury, the cells respond by triggering protective mechanisms, by changing the endocannabinoid system (ECS) which comprises both $\mathrm{CB}_{1}$ and $\mathrm{CB}_{2}$ cannabinoid receptors and their endogenous ligands. The aim of our study was to seek out evidence for the presence of cannabinoid receptors in inflammatory endometrial tissue as well as for their potential role in endometrial inflammation. Our results showed a selective up-regulation of both transcription and expression of $\mathrm{CB}_{2}$ receptors in biopsies from women affected by endometrial inflammation compared to healthy women. The experiments with the nitric oxide-donor SNitroso-L-Glutathione (GSNO) suggest that such a selective up-regulation may be related to the nitric oxide release occurring during endometrial inflammation. In addition, we demonstrated an increase in chymase expression, a marker of mast cells, in biopsies of women affected by endometritis. Therefore our results support the hypothesis that the up-regulation of $\mathrm{CB}_{2}$ occurs mainly on mast cells and that it might tend to sensitize these cells to the anti-inflammatory effect exerted by endogenous cannabinoids by binding their receptor and thus preventing the mast cell degranulation and the release of pro-inflammatory mediators. In conclusion, we believe that the selective $\mathrm{CB}_{2}$ up-regulation might play a role as a novel prognostic factor in endometrial inflammation.

Keywords: endometrial inflammation $\bullet$ nitric oxide $\bullet$ mast cell $\bullet$ chymase $\bullet \mathrm{CB}_{1} \bullet \mathrm{CB}_{2}$.

\section{Introduction}

Endometritis is defined as an inflammation of the endometrium usually resulting from an ascending

${ }^{*}$ Correspondence to: Teresa IUVONE,

Dipartimento di Farmacologia Sperimentale, Università

'Federico II', Via D. Montesano 49, Napoli 80131 Italy.

Tel: +39-08 1678429

Fax:+39-08 1678403

E-mail: iuvone@unina.it infection from the lower genital tract. Clinically significant acute endometritis is usually associated with pregnancy or abortion, as described elsewhere [1, 2]. Currently, a precise histological definition of endometritis clearly discerning between acute and chronic disease is hampered by the wide range of different features observed. Indeed, the inflammatory infiltrate may be confined to the surface of epithelium 
or spread more deeply into the stroma; also, inflammatory cells may include neutrophils and/or plasma cells; furthermore inflammatory mononuclear cells may be hard to differentiate from endometrial stromal cells; finally, the two phases of inflammation may often merge each other and co-exist [3].

An immunological/inflammatory aetiology of endometritis has been demonstrated by the elevated concentrations of leucocytes [4], plasma cells and T cells [5] observed in the inflammatory endometrial infiltrate of affected patients. An increased amount of activated mast cells has been also described in endometrial immune inflammations [6]. All these inflammatory cells locally secrete several pro-inflammatory products including growth factors, cytokines and possibly free oxygen radicals such as nitric oxide (NO), which amplify the inflammatory process.

It has been demonstrated that women with endometrial inflammation have significantly higher levels of inducible nitric oxide synthase (iNOS) expression and NO production compared to healthy women [7, 8]. High levels of NO are involved in antimicrobial and anti-tumoural activities of activated macrophages and an increase of NO is likely to exhibit pro-inflammatory effects [7]. Indeed, low levels of NO seem to be important for a number of essential physiological processes, including maintenance of smooth muscle tone, neurotransmission and modulation of apoptosis [9].

It has been speculated that cannabinoids exert a wide array of effects on the central nervous system (CNS) as well as on peripheral sites including the immune, cardiovascular, digestive, reproductive and ocular systems [10]. Currently, it is widely accepted that most of these effects are mediated by the activation of specific $G$ protein-coupled receptors normally bound by a family of endogenous ligands, the endocannabinoids [11]. Two different cannabinoid receptors have so far been characterized and cloned from mammalian tissues: the $\mathrm{CB}_{1}$ receptor, which is mainly expressed in the brain which is responsible for the psychoactive proprieties of cannabinoids [12], and the $\mathrm{CB}_{2}$ receptor, which is primarily present on cells from the immune system and is likely to be unrelated to cannabinoid psychoactivity [13]. Nevertheless, the co-expression of both $\mathrm{CB}_{1}$ and $\mathrm{CB}_{2}$ receptors on immune system cells has been extensively documented [14], among them mast cells also express both $\mathrm{CB}_{1}$ and $\mathrm{CB}_{2}$ exhibiting differential roles during antigen-driving mast cell response [15]. Recently, it has been demonstrated that 2-arachydonoyl glycerol, the endocannabinoid which preferentially binds to $\mathrm{CB}_{2}$ receptors, decreases the immunological activation of guinea pig mast cells [16]. Such potentially anti-inflammatory properties of cannabinoids prompted us to seek out further evidence for the presence of $\mathrm{CB}$ receptors in human biopsies from women affected by endometrial inflammation, since previous studies have indicated that endocannabinoid receptors expression may be modulated by a number of pro-inflammatory mediators, including NO and cytokines [17, 18].

\section{Materials and method}

Fifteen patients (Group A) diagnosed as having endometritis by means of targeted biopsies performed during outpatient hysteroscopies were enrolled in the study. Twenty patients (Group B) matched for age, BMI and parity undergoing an office hysteroscopy plus targeted biopsies for benign conditions constituted the control group.

All patients signed an informed consent to participate to the study. The study was approved by our Institutional Review Board.

All hysteroscopies were performed by the same operator (A.D.S.) using a $5 \mathrm{~mm}$ continuous-flow operative office hysteroscope with a $2.9 \mathrm{~mm}$ rod lens (Bettocchi office hysteroscope, Karl Storz, Tuttlingen, Germany). All the procedures were carried out under an outpatient regimen being neither analgesia nor local anaesthesia administered to the patient. Distension of the uterine cavity was obtained using normal saline solution and the intrauterine pressure was automatically controlled by an electronic irrigation and suction device (Endomat, Karl Storz, Tuttlingen, Germany). The intrauterine pressure was set at $45 \mathrm{mmHg}$, being the balance of irrigation flow around $200 \mathrm{ml} / \mathrm{min}$ and a vacuum of 0.2 bars.

Hysteroscopies were performed during the follicular phase of cycle (pre-menopausal patients) or within 2 weeks before the surgical procedure (postmenopausal patients).

None of the patients had received any hormonal or antibiotic treatment in the 6 months before the hysteroscopy.

\section{Chemicals}

All materials for biopsies culture were purchased from Biowittaker (Caravaggio, BG, Italy). GSNO was purchased from Sigma (Milan, Italy). $\mathrm{CB}_{1}$ and $\mathrm{CB}_{2}$ receptor antibodies for immunoblotting were purchased from SpioBio 
(Freemont CA, USA); iNOS antibody was purchased from BD Biosciences (Pharmingen, Milan, Italy) and anti-chy-mase from Sigma.

\section{Histological features}

Formalin-fixed, paraffin-embedded tissues from endometrial biopsies were retrieved from the pathology files at the Federico II University of Naples - Italy. The tissue was sectioned at $5 \mu \mathrm{m}$, and stained with haematoxylin and eosin.

\section{Tissue culture}

Endometrial biopsies were placed in 24-well culture plates and cultured in Dulbecco Modified Eagle's Medium (DMEM) supplemented with 5\% Foetal Bovine Serum (FBS), $2 \mathrm{mM}$ glutamine, $100 \mathrm{U} / \mathrm{ml}$ penicillin, $100 \mu \mathrm{g} / \mathrm{ml}$ streptomycin at $37^{\circ} \mathrm{C}$ in $5 \% \mathrm{CO}_{2} / 95 \%$ air for $24 \mathrm{hrs}$ according to Coeffier [19]. In some experiments, the S-Nitroso-LGlutathione (GSNO) $(100 \mu \mathrm{M})$, a NO-generating compound [20], was added to cultured biopsies from healthy women. After 24 hrs of GSNO-stimulation, the biopsies were frozen in liquid nitrogen for further analysis.

\section{MPO activity}

Myeloperoxidase (MPO) activity, an indicator of polymorphonuclear (PMN) accumulation, was determined as previously described [21]. Endometrial tissues, collected at the end of the reperfusion period, were homogenised in a solution containing $0.5 \%(\mathrm{w} / \mathrm{v})$ hexadecyl-trimethyl-ammonium bromide dissolved in $10 \mathrm{mM}$ potassium phosphate buffer $(\mathrm{pH} 7)$ and centrifuged for $30 \mathrm{~min}$ at $20,000 \mathrm{~g}$ at $4^{\circ} \mathrm{C}$. An aliquot of the supernatant was then allowed to react with a solution of tetra-methyl-benzidine $(1.6 \mathrm{mM})$ and $0.1 \mathrm{mM}$ $\mathrm{H}_{2} \mathrm{O}_{2}$. The rate of change in absorbance was spectrophotometrically measured at $650 \mathrm{~nm}$. MPO activity was defined as the quantity of enzyme degrading $1 \mathrm{mmol}$ of hydrogen peroxide $/ \mathrm{min}$ at $37^{\circ} \mathrm{C}$ and was expressed in units per gram weight of wet tissue.

\section{Nitrite assay}

Nitrite production, as the stable metabolites of NO, was measured in 24-hrs-cultured biopsy supernatants by using the method previously described [17]. Briefly, the medium of cultured biopsies $(0.1 \mathrm{ml})$ was added to an equal amount of Griess reagent ( $1 \%$ sulphanilamide, $0.1 \%$ naphtylendiammine, $2.5 \% \mathrm{H}_{3} \mathrm{PO}_{4}$ ) and kept at room tem- perature for $10 \mathrm{~min}$. The absorbance of constituted chromophore was determined using a UV/visible spectrophotometer at $550 \mathrm{~nm}$. Nitrite levels were determined using a sodium nitrite standard curve and expressed as $\mu \mathrm{M} /$ tissue protein.

\section{mRNA analysis}

The mRNA level of $\mathrm{CB}_{2}$ in endometrial tissue was determined using the semiquantitative. RT-PCR method. Total mRNA was extracted using an ultrapure TRIzol reagent (Gibco BRL, Milan, Italy) as directed by the manufacturer. The concentration and purity of total RNA were determined from the A260/A280 ratio using a UV spectrophotometer DU 40 (Beckman, Fullerton, CA, USA). The primer sequences used for PCR amplification were sense 5'$\mathrm{TA}(\mathrm{C} / \mathrm{T}) \mathrm{CC}(\mathrm{G} / \mathrm{A}) \mathrm{CCT}(\mathrm{A} / \mathrm{T}) \mathrm{CCTACAAAGCTC}-3$, and antisense 5'-CC(A/T)GGCACCTGCCTGTCCTGGTG-3' for $\mathrm{CB}_{2}$ receptor and sense: 5'-ATGAAGATCCTGACCGCGCGT- 3', antisense: 5'-AACGCAGCTCAGTAACAGTCCG- 3' for -actin. $1 \mu \mathrm{g}$ of total RNA from each specimen was subjected to RT-PCR. RT-PCR was carried out by using a SuperScript TM One-Step RT-PCR with Platinum Taq Kit in a total reaction volume of $25 \mu$ l, containing $2 X$ reaction mix $12.5 \mu \mathrm{l}, 25 \mu \mathrm{mol} / \mathrm{L}$ sense primer $0.5 \mu \mathrm{l}$, $25 \mu \mathrm{mol} / \mathrm{L}$ anti-sense primer $0.5 \mu \mathrm{l}$, RT-PCR platinum Taq mix $0.5 \mu \mathrm{l}$ and autoclaved distilled water. The $\beta$-actin and $\mathrm{CB}_{2}$ PCR products were electrophoresed on $1 \%$ agarose gel and visualized by staining with ethidium bromide. The integrated density values of the bands representing amplified products were acquired and analysed by GS 700 Imaging Densitometer (Bio-Rad) and a computer program (Molecular Analyst IBM).

\section{Isolation of mast cells from endometrial tissues}

Human mast cells (MCs) were isolated from endometrial biopsies by means of enzymatic digestion as previously described [22]. Briefly, endometrial tissues were placed into $\mathrm{Ca} / \mathrm{Mg}$-free Tyrode's buffer. Thereafter, tissue was chopped into small pieces, and the fragments were extensively washed in Tyrode's buffer. Incubation was carried out at $37^{\circ} \mathrm{C}$ for $120 \mathrm{~min}$ by addition of collagenase $(30 \mathrm{U} / \mathrm{ml})$. The dispersed cells were recovered by filtration through Nytex cloth. After washing twice in $0.9 \% \mathrm{NaCl}$, the cell suspension was incubated with DNAse $(0.5 \mathrm{mg} / \mathrm{ml})$, hyaluronidase $(0.5 \mathrm{mg} / \mathrm{ml})$ and pronase-E $(2 \mathrm{mg} / \mathrm{ml})$ for $15 \mathrm{~min}$ at $37^{\circ} \mathrm{C}$. Cells were washed three times in $\mathrm{NaCl}$ at room temperature. The percentage of MCs was determined by toluidine blue staining. Isolated MCs were cultured in RPMI-1640 medium supplemented with $10 \%$ foetal calf serum, glutamine and antibiotics at $37^{\circ} \mathrm{C}$ for at least $24 \mathrm{hrs}$ before the analysis. 


\section{$\beta$-Hexosaminidase analysis}

Mast cells were stimulated with the calcium ionophore, A23187 (500 nM) (Sigma Aldrich), in presence or absence of $\mathrm{CB}_{2}$ selective agonist, JWH-015 $\left(10^{-8}-10^{-6} \mathrm{M}\right)$.

Mast cell degranulation was detected by measuring the release of the granular enzyme $\beta$-hexosaminidase using a method first described by Hernandez-Hansen et al. [23].

Aliquots $(50 \mu \mathrm{l})$ of cell medium were collected from each well and transferred into a 96-well plate. Substrate, p-nitrophenyl Nacetyl- $\beta$-D-glucosaminide $(50 \mu \mathrm{l}$ of a $2 \mathrm{mM}$ solution diluted in $0.2 \mathrm{M}$ citrate buffer, $\mathrm{pH} 4.5$ ), was added to each well. The samples were then incubated with the substrate for $2 \mathrm{hrs}$ at $37^{\circ} \mathrm{C}$. All incubations were carried out at this temperature because all the reactions are sensitive to temperature changes. Medium and chemicals were also kept at $37^{\circ} \mathrm{C}$ throughout the experiment to avoid an undesired impact on the result caused by any temperature changes. After $2 \mathrm{hrs}$, reactions were terminated by adding $150 \mu \mathrm{l}$ of $1 \mathrm{M}$ Tris-buffer $\mathrm{pH}$ 9.0. The absorbances were measured in a microplate reader at $405 \mathrm{~nm}$. The total $\beta$-hexosaminidase cell content was determined in parallel wells where the cells were dissolved in $0.01 \%$ Triton X-100. The background release from unstimulated cells was also determined. Mast cell degranulation was expressed as percentage of $\beta$-hexosaminidase release.

\section{Western blot analysis}

Depending upon the experiments, fresh or GSNO-stimulated biopsies were weighted and rapidly homogenized in $60 \mu \mathrm{l}$ of ice-cold hypotonic lysis buffer (10 mM HEPES, $1.5 \mathrm{mM}$ $\mathrm{MgCl}_{2}, 10 \mathrm{mM} \mathrm{KCl}, 0.5 \mathrm{mM}$ phenylmethylsulfonyl fluoride, $1.5 \mu \mathrm{g} / \mathrm{ml}$ soybean trypsin inhibitor, pepstatin A $7 \mu \mathrm{g} / \mathrm{ml}$, leupeptin $5 \mu \mathrm{g} / \mathrm{ml}, 0.1 \mathrm{~mm}$ benzamidine, $0.5 \mathrm{mM}$ dithiothreitol [DTT]) and incubated in ice for $45 \mathrm{~min}$. The cytoplasmic fractions were then obtained by centrifugation at $13,000 \mathrm{~g}$ for $1 \mathrm{~min}$ and protein concentration in the samples was determined using a Bio-Rad assay kit according to the manufacturer's instructions. Immunoblotting analysis of iNOS, $\mathrm{CB}_{1}, \mathrm{CB}_{2}$ receptors and chymase were performed on a cytosolic fraction of cultured specimens. Cytosolic fraction proteins were mixed with gel loading buffer $(50 \mathrm{mM}$ Tris, $10 \%$ SDS, $10 \%$ glycerol 2-mercaptoethanol, 2 mg bromophenol/ $\mathrm{ml}$ ) in a ratio of $1: 1 \mathrm{v} / \mathrm{v}$, boiled for $5 \mathrm{~min}$ and centrifuged at $10,000 \mathrm{~g}$ for $10 \mathrm{~min}$. Protein concentration was determined and equivalent amounts $(50 \mu \mathrm{g})$ of each sample were separated under reducing conditions in $12 \%$ SDSpolyacrylamide minigel. The proteins were transferred onto nitrocellulose membrane according to the manufacturer's instructions (Bio-Rad Laboratories, Hercules, CA, USA). Depending upon the experiments, the membranes were blocked by incubation at $4^{\circ} \mathrm{C}$ overnight in high salt buffer
(50 mm Trizma base, $500 \mathrm{~mm} \mathrm{NaCl}, 0.05 \%$ Tween-20) containing $5 \%$ bovine serum albumin; they were then incubated for $1 \mathrm{hr}$ with anti-iNOS (1:2000 v/v) (BD Biosciences, Pharmingen, Italy), anti-CB1 (1:250 v/v), anti-CB 2 (1:250 $\mathrm{v} / \mathrm{v})$ anti-Chymase (1:250 v/v) (NeoMarkers, Freemont, CA) or anti-tubulin (1:1000 v/v) (Sigma-Aldrich, Milano, Italy) for $2 \mathrm{hrs}$ at room temperature, followed by incubation with specific horseradish peroxidase (HRP)-conjugate secondary antibody (Dako, Golstrup, DK). The immune complexes were developed using enhanced chemiluminescence detection reagents (Amersham, Italy), according to the manufacturer's instructions and exposed to Kodak X-Omat film. The bands of proteins on X-ray film were scanned and analysed with a GS-700 imaging densitometer (Bio-Rad Laboratories, CA, USA).

\section{Results}

\section{Histological features of endometrial biopsies}

Endometrial biopsies obtained from patients enrolled in Group A showed a significant increase in both mononuclear inflammatory cells and granulocytes which filled and destroyed the endometrial glands. The diagnosis of endometritis was done according to the established criteria [24].

Endometrial biopsies obtained from patients enrolled in Group B did not show any feature suggestive of endometrial inflammation (Fig. 1A and B).

\section{MPO activity}

Biopsies obtained from patients affected by endometritis were characterized by an increase in MPO activity, an indicator of PMN infiltration, compared to healthy patients (Fig. 1C), thus confirming the occurrence of an inflammatory reaction in the endometrial tissue.

\section{Expression of mast-cell chymase in biopsies of patients with endometritis}

Western blot analysis of biopsies obtained from patients affected by endometritis revealed an increase in chymase expression, a specific preformed mediator released by MCs, compared to healthy patients (Fig. 2), thus confirming the presence of MCs in the inflammatory endometrial tissue. 


\section{Increased nitrite levels and iNOS protein expression in cultured biopsies}

When biopsies from patients harbouring endometritis were cultured for $24 \mathrm{hrs}$ at $37^{\circ} \mathrm{C}$, nitrite levels, the sta-ble metabolite of nitric oxide, were significantly increased compared to biopsies from healthy patients (Fig. 3C). Immunoblotting analysis of the tissues revealed that iNOS protein expression was significantly increased in endometrial biopsies from patients affected by endometritis versus healthy patients (Fig. $3 \mathrm{~A}$ and $\mathrm{B}$ ).

\section{Selective up-regulation of $\mathrm{CB}_{2}$ receptor in biopsies of patients with endometritis}

Immunoblotting analysis revealed that $\mathrm{CB}_{2}$ receptor protein expression was significantly increased in endometrial biopsies from patients affected by endometritis compared to healthy patients. Interestingly, no significant differences in $\mathrm{CB}_{1}$ receptor protein expression were observed in the biopsies deriving from the two groups of patients (Fig. 4A, B and Fig. 5A, B).

Moreover, RT-PCR analysis revealed that $\mathrm{CB}_{2}$ receptor mRNA expression was significantly increased in endometrial biopsies deriving from patients affected by endometritis compared to healthy patients (Fig. 6).

\section{Selective up-regulation of $\mathrm{CB}_{2}$ receptor by GSNO}

Western blot analysis of biopsies stimulated for 24 hrs with the NO donor, GSNO $(100 \mu \mathrm{M})$, showed a sig-nificant and selective increase of $\mathrm{CB}_{2}$ receptor pro-tein expression compared to unstimulated biopsies. On the contrary, no differences in $\mathrm{CB}_{1}$ receptor expression were observed between GSNO-stimulated and unstimulated endometrial biopsies (Fig. 4C, D and Fig. 5C, D).

\section{Effect of JWH-015 on A23187-induced mast cell degranulation}

The MC secretagogue calcium ionophore A23187 $(500 \mathrm{nM})$ [25] induced a significant increase of
A

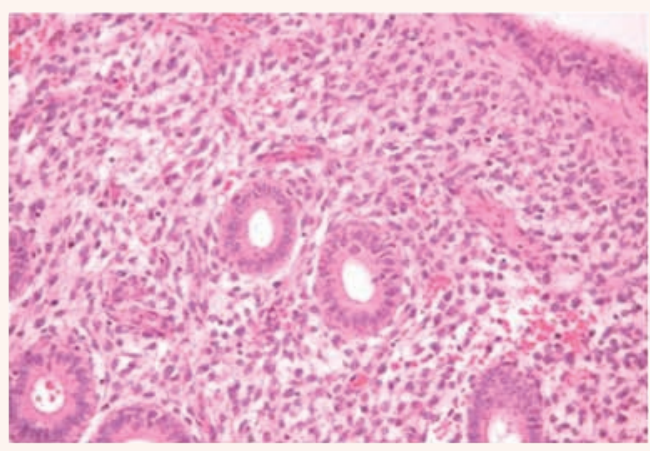

Ctr

B

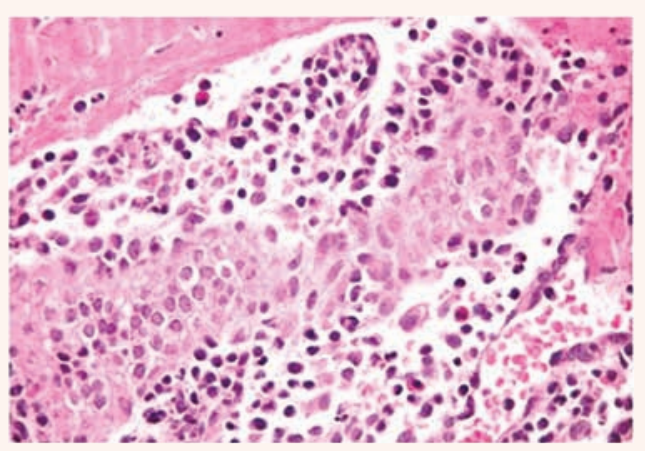

endometritis

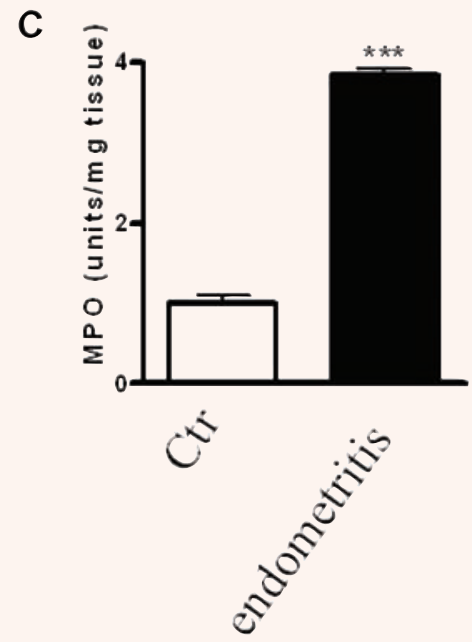

Fig. 1 Inflammatory environment: representative histological analysis of endometrial biopsies from healthy women (A) and women suffering endometritis (B). Polymorphonuclear cell infiltration in biopsies from healthy women and women suffering endometritis, detected by myeloperoxidase activity assay (C). Each bar shows the mean \pm SEM of six experiments. ${ }^{\star \star \star} P<0.001$ versus healthy patients. 


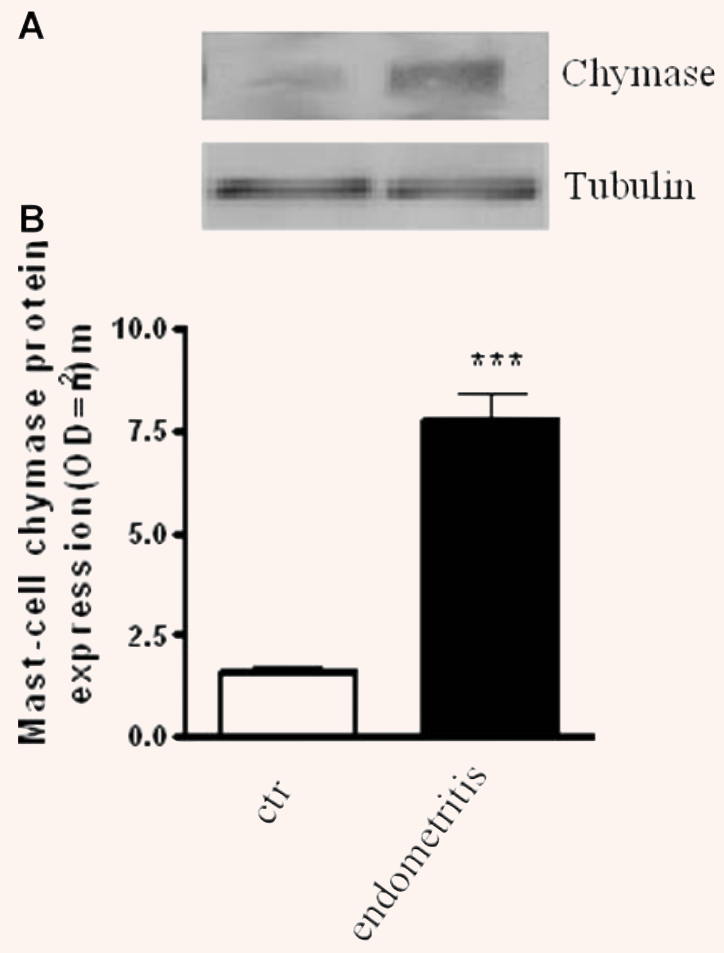

Fig. 2 Representative Western blot analysis (A) and relative densitometric analysis (B) of chymase (MW 45 $\mathrm{kD}$ ), a marker of mast cells, in biopsies from healthy women and women suffering of endometritis. Tubulin expression is shown as control. Data are representative of six separated experiments. Each bar in the graph shows the mean \pm SEM of six experiments. ${ }^{\star * \star} P<0.001$ versus healthy patients.

human $\mathrm{MC}$ degranulation. Treatment of endometrial MCs with the selective $\mathrm{CB}_{2}$ agonist JWH-015 $\left(10^{-8}-\right.$ $\left.10^{-6} \mathrm{M}\right)$ reduced $\mathrm{A} 23187$-induced degranulation in a concentration-dependent manner (Fig. 7).

\section{Discussion}

In the present study, we have observed, for the first time, a significant and selective increase in both $\mathrm{CB}_{2}$ receptor transcription and expression in endometrial biopsies obtained from women affected by endometrial inflammation compared to healthy women.
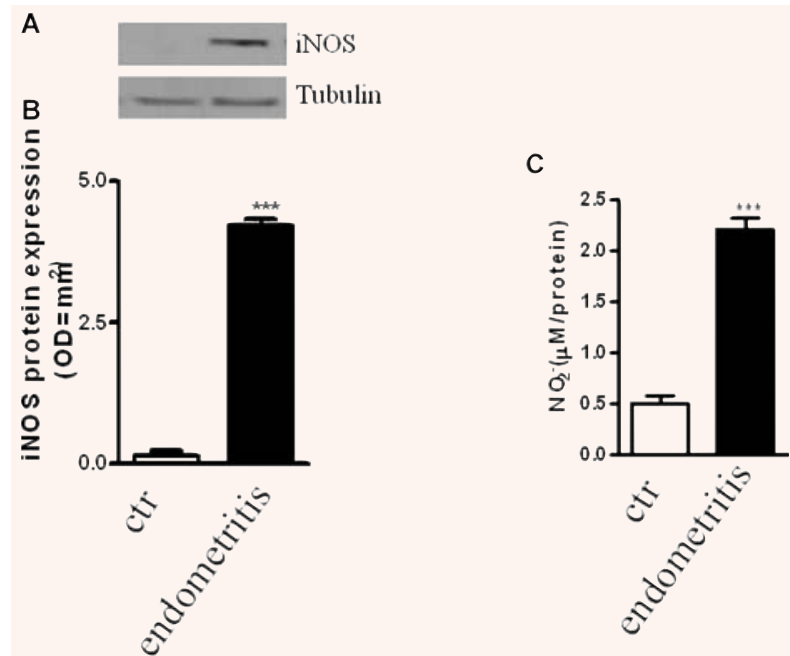

Fig. 3 Representative Western blot analysis (A) and relative densitometric analysis (B) of iNOS (130 kD) protein expression in endometrial biopsies from healthy women and women suffering endometritis. (C) NO production from cultured biopsies from inflamed and healthy patients. Each bar shows the mean \pm SEM of eight experiments. ${ }^{\star \star \star} P<0.001$ versus healthy patients.
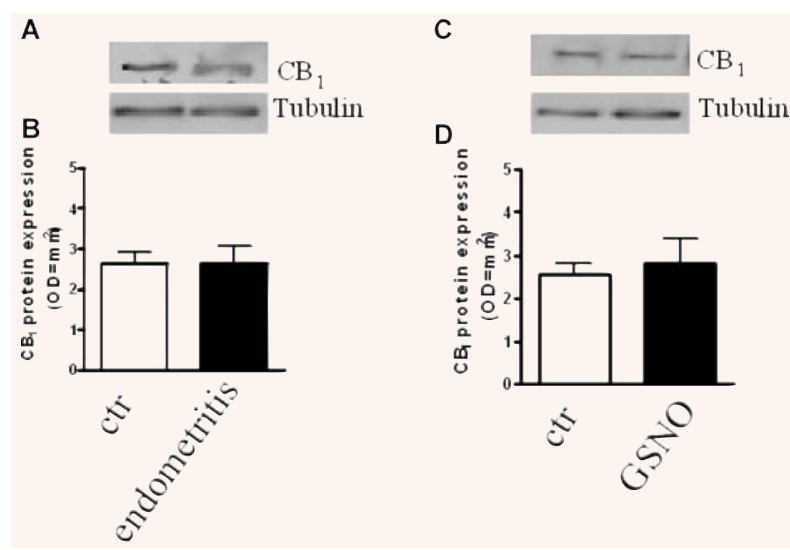

Fig. 4 Western blot analysis of CB1 (MW 60 kD) expression in: (A) endometrial biopsies from healthy women and women suffering endometritis; (C) endometrial biopsies stimulated with GSNO; (B and $\mathbf{D})$ relative densitometric analysis. Each bar shows the mean \pm of SEM of six experiments.

Histological analysis of such biopsies have revealed an increased amount of inflammatory cells; in addition, we have observed an increase in both chymase, a marker of MCs [26], and myeloperoxydase, a marker of infiltrating leucocytes [27], compared 

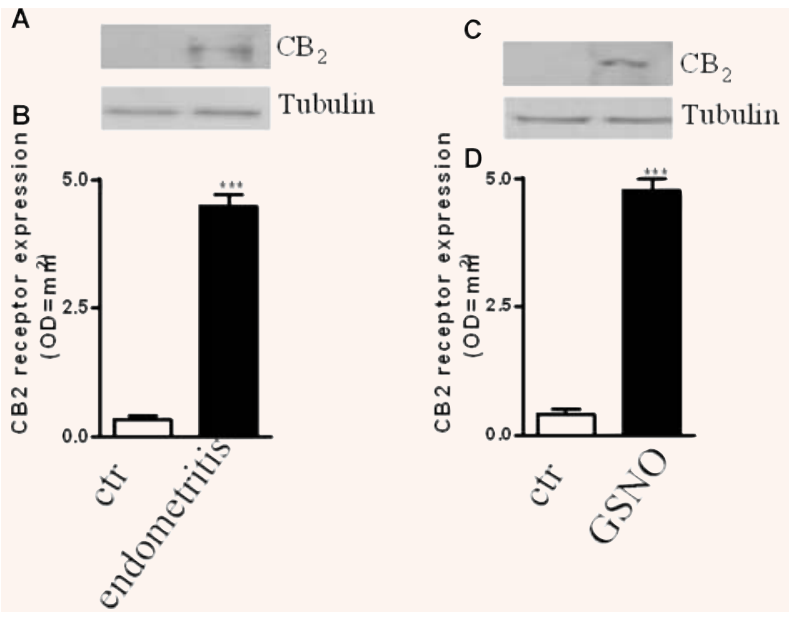

Fig. 5 Western blot analysis of CB2 (MW 45 kD) expression in: (A) endometrial biopsies from healthy women and women suffering of endometritis; (C) endometrial biopsies stimulated with GSNO. (B and $\mathbf{D})$ relative densitometric analysis. Each bar shows the mean \pm of SEM of six experiments. ${ }^{* *} P<0.001$ versus healthy patients.

to healthy patients' biopsies. All these infiltrating cells sustain the inflammatory environment by releasing a number of pro-inflammatory mediators, including cytokines, growth factors and free radical species [28]. Cultured biopsies obtained from women affected by endometrial inflammation, released an increased amount of NO produced by the inducible isoform of NOS. Physiologically, consequently to NO-sustained inflammation, the immune cells respond by triggering protective mechanisms, including the capture of free radicals and the bio-transformation of xenobiotics [29]. Recently it has been shown that inflammatory stimuli, such as lipopolysaccharide (LPS), may affect the endocannabinoid system by increasing AEA production in rat macrophages and 2-AG in rat platelets [30]. Our findings indicate that NO, one of the most important mediators of the inflammatory environment, modulates cannabinoid receptor expression. Indeed, we have found that stimulation with GSNO, a compound able to mimic the inflammatory scenario, by releasing NO, selectively increased $\mathrm{CB}_{2}$ receptor expression when added to biopsies of healthy patients. The mechanism at the basis of this effect has not been further elucidated but the occurrence of this effect is very likely, since the endocannabinoid system is known to control inflammatory processes [31].

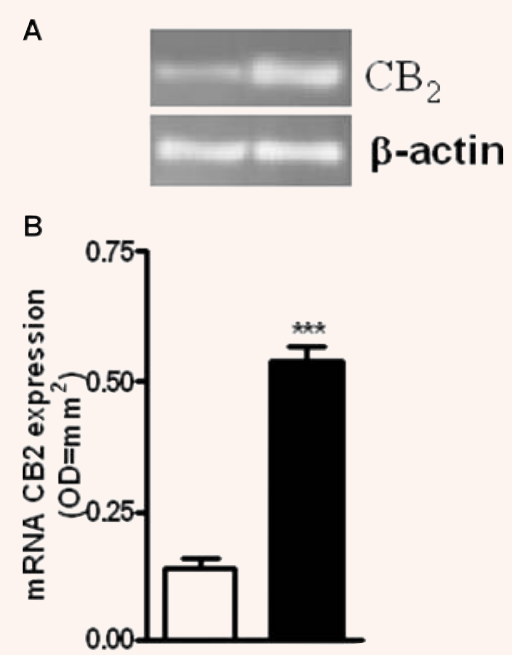

Fig. $6 \mathrm{CB}_{2}$ mRNA expression in endometrial biopsies from healthy women and women suffering of endometritis (A) and relative densitometric analysis (B). The expression of $\beta$-actin was used as a control. Each bar shows the mean \pm of SEM of six experiments. ${ }^{* *} P<0.001$ versus healthy patients.

Our findings support the hypothesis that the selective up-regulation of $\mathrm{CB}_{2}$ receptor may be a responsive mechanism triggered by injured endometrial tissue to control the NO-sustained inflammatory reaction. In fact, several studies have shown that cannabinoids exhibit anti-inflammatory proprieties, both in laboratory animals [32] and cell cultures [33], by modulating key pathways of the inflammatory process, thereby directly inhibiting pro-inflammatory mediator release. Such anti-inflammatory activity can be explained by the property of cannabinoids to bind to specific receptors expressed on the surface membrane of several inflammatory cells. In addition, our findings seem to support the hypothesis that the up-regulation of cannabinoid receptors occurs mainly on MCs. Indeed, MCs were highly expressed in biopsies from women affected by endometritis in agreement with previous findings describing $\mathrm{MC}$ infiltration and accumulation in endometrial inflammation [6]. Moreover, the $\mathrm{CB}_{2}$ receptor activation on isolated 


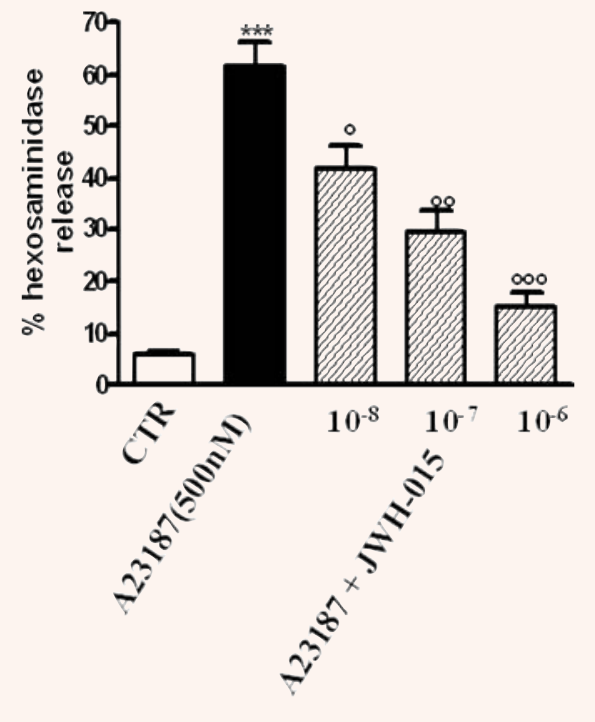

Fig. 7 Effect of JWH-015 on A23187-induced mast cell degranulation. Mast cells were isolated from inflamed women's biopsies. Each bar shows the mean \pm of SEM of three separated experiments ${ }^{* *} P<0.001$ versus CTR; ${ }^{\circ} P<0.05,{ }^{\circ} P<0.01,{ }^{\circ \circ} P<0,001$ versus $A 23187$.

endometrial MCs, leads to the inhibition of A23187induced degranulation. During inflammatory process, MCs release their stored and newly synthesized mediators either via the classical immunological IgE-dependent activation or in response to a variety of stimuli [34]. Mast cell mediators include cytokines (tumour necrosis factor [TNF]- $\alpha$ ), histamine and proinflammatory mediators such as NO, inter-leukin (IL)1 and IL-6 [35]. Therefore, we can speculate that the up-regulation of $\mathrm{CB}_{2}$ might occur to sensitize MCs to the anti-inflammatory effect exerted by endogenous endocannabinoids, by binding to the $\mathrm{CB}_{2}$ receptor, and thus preventing both the degranulation and the release of pro-inflammatory mediators from MCs.

In conclusion, in view of the fact that nowadays ongoing studies using techniques of molecular biology and immunohistochemistry are trying to identify new prognostic factors to be correlated to the endometrial inflammatory process to support the still controversial histological diagnosis of endometritis [36], we believe that the selective $\mathrm{CB}_{2}$ up-regulation might play a role as a novel prognostic factor in endometrial inflammation.

\section{Acknowledgement}

We thank Dott.ssa Elena Greco for revising our manuscript.

\section{References}

1. Poropatich C, Rojas M, Silverberg SG. Polymorphonuclear leucocytes in the endometrium during the normal menstrual cycle. Int $J$ Gynecol Pathol. 1987; 6: 230-4.

2. Molnar JJ, Poliak A. Recurrent endometrial malakoplakia. Am J Clin Pathol. 1983; 80: 762-4.

3. Ross JD. What is endometritis and does it require treatment? Sex Transm Infect. 2004; 80: 252-3.

4. Disep B, Innes BA, Cochrane HR, Tijani S, Bulmer JN. Immunohistochemical characterization of endometrial leucocytes in endometritis. Histopathology. 2004 45: 625-32.

5. Dechaud H, Maudelonde T, Daures JP, Rossi JF, Hedon B. Evaluation of endometrial inflammation by quantification of macrophages, $\mathrm{T}$ lymphocytes, and interleukin-1 and -6 in human endometrium. J Assist Reprod Genet. 1998; 15: 612-8.

6. Sugamata M, Ihara T, Uchiide I. Increase of activated mast cells in human endometriosis. Am J Reprod Immunol. 2005; 53: 120-5.

7. Weinberg JB. Nitric oxide production and nitric oxide synthase type 2 expression by human mononuclear phagocytes: a review. Mol Med. 1998; 4: 557-91.

8. Osborn BH, Haney AF, Misukonis MA, Weinberg JB. Inducible nitric oxide synthase expression by peritoneal macrophages in endometriosis-associated infertility. Fertil Steril. 2002; 77: 46-51.

9. Di Rosa M, lalenti A, lanaro A, Sautebin L. Interaction between nitric oxide and cyclooxygenase pathways. Prostaglandins Leukot Essent Fatty Acids. 1996; 54: 229-38.

10. Di Marzo, Bisogno T, De Petrocellis L. Endocannabinoids: new targets for drug development. Curr Pharm Des. 2000; 6:1361-80.

11. Bisogno T, Ligresti A, Di Marzo V. The endocannabinoid signalling system: biochemical aspects. Pharmacol Biochem Behav. 2005; 81: 224-38.

12. Pertwee RG. Evidence for the presence of CB1 cannabinoid receptors on peripheral neurones and 
for the existence of neuronal non-CB1 cannabinoid receptors. Life Sci. 1999; 65: 597-605.

13. Matias I, Pochard P, Orlando P, Salzet M, Pestel J, Di Marzo V. Presence and regulation of the endocannabinoid system in human dendritic cells. Eur $J$ Biochem. 2002; 269: 3771-8.

14. Croxford JL, Yamamura T. Cannabinoids and the immune system: potential for the treatment of inflammatory diseases? J Neuroimmunol. 2005; 166: 3-18.

15. Samson MT, Small-Howard A, Shimoda LM, Koblan-Huberson $M$, Stokes AJ, Turner HJ. Differential roles of CB1 and CB2 cannabinoid receptors in mast cells. Immunol. 2003; 170: 4953-62.

16. Vannacci A, Giannini L, Passani MB, Di Felice A, Pierpaoli S, Zagli G, Fantappie O, Mazzanti R, Masini E, Mannaioni PF. The endocannabinoid 2arachidonylglycerol decreases the immunological activation of Guinea pig mast cells: involvement of nitric oxide and eicosanoids. J Pharmacol Exp Ther. 2004; 311: 256-64.

17. Esposito G, Ligresti A, Izzo AA, Bisogno T, Ruvo M, Di Rosa M, Di Marzo V, luvone T. The endocannabinoid system protects rat glioma cells against HIV-1 Tat protein-induced cytotoxicity. Mechanism and regulation. J Biol Chem. 2002; 277: 50348-54.

18. Maresz K, Carrier EJ, Ponomarev ED, Hillard CJ, Dittel BN. Modulation of the cannabinoid CB2 receptor in microglial cells in response to inflammatory stimuli. J Neurochem. 2005; 95: 437-45.

19. Coeffier M, Le Pessot F, Leplingard A, Marion R, Lerebours E, Ducrotte P, Dechelotte P. Acute enteral glutamine infusion enhances heme oxygenase- 1 expression in human duodenal mucosa. $J$ Nutr. 2002; 132: 2570-3.

20. Radomski M. W., Rees DD, Dutra A, Moncada S. S-nitroso-glutathione inhibits platelet activation in vitro and in vivo. Br. J. Pharmacol. 1992; 107: 745-9.

21. Mullane KM, Kraemer R, Smith BJ. Myeloperoxidase activity as a quantitative assessment of neutrophil infiltration into ischemic myocardium Pharmacol Methods. 1985; 14: 157-67.

22. Sperr WR, Bankl HC, Mundigler G, Klappacher G, Grossschmidt K, Agis H, Simon P, Laufer P, Imhof M, Radaszkiewicz T, Glogar D, Lechner K, Valent P. The human cardiac mast cell: localization, isolation, phenotype, and functional characterization. Blood. 1994; 84: 3876-84.

23. Hernandez-Hansen V, Smith AJ, Surviladze Z, Chigaev A, Mazel T, Kalesnikoff J, Lowell CA, Krystal G, Sklar LA, Wilson BS, Oliver JM.
Dysregulated FcepsilonRI signaling and altered Fyn and SHIP activities in Lyn-deficient mast cells. $J$ Immunol. 2004; 173: 100-12.

24. Kiviat NB, Wolner-Hanssen P, Eschenbach DA, Wasserheit JN, Paavonen JA, Bell TA, Critchlow CW, Stamm WE, Moore DE, Holmes KK. Endometrial histopathology in patients with cultureproved upper genital tract infection and laparoscopically diagnosed acute salpingitis. Am J Surg Pathol. 1990; 14: 167-75.

25. Klein LM, Lavker RM, Matis WL, Murphy GF. Degranulation of human mast cells induces an endothelial antigen central to leukocyte adhesion. Proc Natl Acad Sci USA. 1989; 86: 8972-6.

26. Li L, Li Y, Reddel SW, Cherrian M, Friend DS, Stevens RL, Krilis SA. Identification of basophilic cells that express mast cell granule proteases in the peripheral blood of asthma, allergy, and drug-reactive patients. J Immunol. 1998; 161: 5079-86.

27. Mulligan MS, Smith CW, Anderson DC, Todd RF $3^{\text {rd }}$, Miyasaka M, Tamatani T, Issekutz TB, Ward PA. Role of leukocyte adhesion molecules in complement-induced lung injury. J Immunol. 1993; 150: 2401-6.

28. Jablonska E, Puzewska W, Grabowska Z, Jablonski J, Talarek L. VEGF, IL-18 and NO production by neutrophils and their serum levels in patients with oral cavity cancer. Cytokine. 2005; 30: 93-9.

29. Berg D, Youdim MB, Riederer P. Redox imbalance. Cell Tissue Res. 2004; 318: 201-13.

30. Maccarrone M, Bari M, Battista N, Finazzi-Agro A. Endocannabinoid degradation, endotoxic shock and inflammation. Curr Drug Targets Inflamm Allergy. 2002; 1: 53-63.

31. Di Marzo V, Izzo AA. Endocannabinoid overactivity and intestinal inflammation. Gut. 2006; 55: 1373-6.

32. van der Stelt M, Mazzola C, Esposito G, Matias I, Petrosino S, De Filippis D, Micale V, Steardo L, Drago F, luvone T, Di Marzo V. Endocannabinoids and beta-amyloid-induced neurotoxicity in vivo: effect of pharmacological elevation of endocannabinoid levels. Cell Mol Life Sci. 2006; 63: 1410-24.

33. Esposito G, De Filippis D, Steardo L, Scuderi C, Savani C, Cuomo V, luvone T. CB1 receptor selective activation inhibits beta-amyloid-induced iNOS protein expression in C6 cells and subsequently blunts tau protein hyperphosphorylation in co-cultured neurons. Neurosci Lett. 2006; 404: 342-6.

34. luvone T, Den Bossche RV, D'Acquisto F, Carnuccio R, Herman AG. Evidence that mast cell degranulation, histamine and tumour necrosis factor 
alpha release occur in LPS-induced plasma leakage in rat skin. Br J Pharmacol. 1999; 128: 700-4.

35. Crivellato E, Ribatti D. Involvement of mast cells in angiogenesis and chronic inflammation. Curr Drug Targets Inflamm Allergy. 2005; 4: 9-11.
36. Mazurek A, Pierzynski P, Kuc P, Kopinski P, Terlikowski S, Niklinska W, Trojan J, Laudanski T. Evaluation of angiogenesis, p-53 tissue protein expression and serum VEGF in patients with endometrial cancer. Neoplasma. 2004; 51: 193-7. 